\title{
Measurement of arachidonate and its metabolites extracted from human normal and malignant gastrointestinal tissues
}

\author{
A BENNETT, A CIVIER, C N HENSBY, P B MELHUISH, AND I F STAMFORD \\ From the Department of Surgery, King's College School of Medicine and Dentistry, The Rayne Institute, \\ London and CIRD, Sophia-Antipolis, Valbonne 06565, France
}

SUMMARY This is the first report of human gastrointestinal arachidonate and prostanoids measured quantitatively by gas chromatography-mass spectrometry (GC-MS) in extracts of human cancers and macroscopically normal tissues from the stomach and colon. There were $\mu \mathrm{g} / \mathrm{g}$ amounts of arachidonate, and the particularly high yield from the tumours may explain why they usually produce more prostaglandins than the normal tissues in which they arise. There was only a small conversion of the arachidonate into prostanoids. 6-Keto-PGF ${ }_{1 \alpha}$ was the most abundant metabolite measured, particularly in the tumour extracts, with smaller amounts of prostaglandins $\mathrm{E}_{2}, \mathrm{~F}_{2 \alpha}$ and $\mathrm{D}_{2}$.

Previous qualitative gas chromatography-mass spectrometry (GC-MS)' has shown that extracts of human homogenised gastrointestinal tissues contain arachidonate, 6-keto- $\mathrm{PGF}_{1 \alpha}$, thromboxane $\mathrm{B}_{2}, 12$ hydroxy-eicosatetraenoate (12-HETE) and usually $\mathrm{PGD}_{2}, \mathrm{PGE}_{2}$ and $\mathrm{PGF}_{2 \alpha}$. Prostaglandin-like substances extracted from various human gastrointestinal tissues have been measured by bioassay ${ }^{2-5}$ and radioimmunoassay, ${ }^{6-9}$ but these have problems of specificity. We now report quantitative measurements of $\mathrm{PGD}_{2}, \mathrm{PGE}_{2}, \mathrm{PGF}_{2 \alpha}, 6$-keto-PGF $\mathrm{PG}_{1 \alpha}$ and free arachidonate by selective ion monitoring GCMS of extracted human normal and malignant gastrointestinal tissues.

\section{Methods}

SPECIMENS

Gastrointestinal tissues were obtained at operation for various malignant or benign disorders, and reached the laboratory within one hour of removal. There were 55 tissues from the stomach and colon, from 23 patients who, as far as we could ascertain,

Address for correspondence: Professor A Bennett, Dept of Surgery, Rayne Institute, 123 Coldharbour Lane, London SE5 9NU.

Received for publication 20 June 1986 had not recently taken any drugs known to affect prostaglandin synthesis. Tumour, and/or macroscopically normal tissue taken at least $5 \mathrm{~cm}$ from the site of any abnormality, were cleared of mesentery and fat, and the mucosal layers separated from the muscle. The fresh muscle, mucosa and/or tumour were cut into small pieces (approximately $2 \mathrm{~mm}^{3}$ ) and washed in Krebs solution. Weighed portions were homogenised $(0 \cdot 1 \mathrm{~g}$ tissue $/ \mathrm{ml} ; 30 \mathrm{~s}$; Silverson homogeniser) at room temperature in Krebs solution, and the individual homogenates were extracted for prostaglandins using chloroform/formic acid."

The methods for gas chromatography-mass spectrometry (GC-MS) were as reported previously.' In brief, the dried extract obtained as described above was dissolved in dichloromethane. An aliquot was taken for GC-MS and further purified by LH20 column chromatography; non-polar impurities were eluted with dichloromethane, and the eicosanoids were eluted with methanol which was then evaporated. Deuterated standards were added, and each dried methanol extract was dissolved in doubledistilled water acidified to $\mathrm{pH} 3$ with hydrochloric acid. Each solution was percolated through an Amberlite column which was then washed with distilled water, and the eicosanoids were eluted with 
methanol. The concentrated methanolic extracts were co-chromatographed simultaneously with authentic standards on silica gel TLC plates using the F6 solvent system of Andersen. ${ }^{11}$

Chemical derivatives were made by forming O-methyloximes, which were converted first into methyl esters and then into trimethylsilyl ethers by heating with $\mathrm{N}, \mathrm{N}-$ bis (trimethylsilyl)-trifluoroacetamide (BSTFA; Sigma), as described previously.' Samples were analysed by selective ion monitoring using a Riber 10-10C mass spectrometer interfaced with a Jirdel 31 gas chromatograph equipped with a 12.5 metre fused SE30 silica capillary column (Hewlett Packard). Helium $2 \mathrm{ml} / \mathrm{min}$ was used as the carrier gas with a column temperature of $210-260^{\circ} \mathrm{C}$. The mass spectrometer was operated at $70 \mathrm{eV}$ electron energy and an electron multiplier setting of $2200 \mathrm{~V}$.

Quantitative selective ion monitoring of derivatised $\mathrm{PGD}_{2}$ (assayed after conversion to $\mathrm{PGF}_{2 \alpha}$ ), $\mathrm{PGE}_{2}, \mathrm{PGF}_{2 \alpha}, 6$-keto-PGF $\mathrm{PG}_{1 \alpha}$ and arachidonate was carried out on the extracted samples with added deuterated standards. Prostanoid standards were obtained from the Upjohn Company, Michigan, USA. The chloroform extraction method gives recoveries of at least $70 \%$ with PGE and PGF compounds;" subsequent recoveries were about $60-80 \%$.

\section{STATISTICAL ANALYSIS}

Results, uncorrected for losses, are expressed as medians with semiquartile ranges in parentheses. Statistical evaluation of the amounts of prostanoids from the same tissue was by the Wilcoxon's matched pairs test, and comparisons between different tissues were by the Mann-Whitney U-test.

\section{Results}

\section{STOMACH}

The gastric tissues were obtained from 10 patients (six men, four women) who underwent surgery for malignant (eight) or benign (two) disease. With the malignant specimens both tumour and macroscopically normal tissues were available in four cases; two of eight provided only tumour, and the other two provided only 'normal' tissues. The tumour extracts contained the greatest amounts of prostaglandins. In all normal and malignant tissue extracts the eicosanoid present in the highest amounts was arachidonate ( $\mu \mathrm{g} / \mathrm{g}$ range). The prostaglandins were present in $\mathrm{ng} / \mathrm{g}$ amounts, with more 6-keto- $\mathrm{PGF}_{1 \alpha}$ than $\mathrm{PGE}_{2}$ (except for the higher amount from one tumour), $\mathrm{PGD}_{2}$ and $\mathrm{PGF}_{2 \alpha}$ (Table 1). The tumours usually yielded more of each substance compared with the mucosa.

\section{LARGE BOWEL}

The specimens of large bowel from 13 patients included five rectal tumours with macroscopically normal sigmoid colonic tissue, three tumours plus normal tissues from the ascending colon, and five samples of macroscopically normal tissues from sigmoid colons removed for carcinoma (no tumour was provided). These specimens are dealt with together because the findings from the two regions were mainly similar.

In colon tumour extracts, arachidonate was always present in the greatest amounts $(\mu \mathrm{g} / \mathrm{g})$. The prostaglandins were present in $\mathrm{ng} / \mathrm{g}$ amounts, and there was always more 6-keto- $\mathrm{PGF}_{1 \alpha}$ than the others (Table 2).

In comparison with the mucosa, all tumours of the large bowel yielded more arachidonate/g tissue. Amounts of $\mathrm{PGE}_{2}$ were higher in six of seven tumour extracts than in the corresponding mucosa $(p<0 \cdot 05)$, and the overall comparison including unpaired tissues was also $p<0 \cdot 05$. The tumour yields were greater than from mucosa in five of seven cases with $\mathrm{PGD}_{2}$ and five of seven cases with $\mathrm{PGF}_{2 \alpha}$; of the two exceptions, one tumour yielded less of both prostaglandins. When paired and unpaired tissues were considered together, the tumour and mucosal amounts were similar (Table 2). Although the overall statistical comparison for 6-keto- $\mathrm{PGF}_{1 \alpha}$, including data from unpaired tissues was $p<0 \cdot 05$, only three of

Table 1 Quantitative measurement of prostaglandins and free arachidonate in extracts of stomach tissues by GC-MS

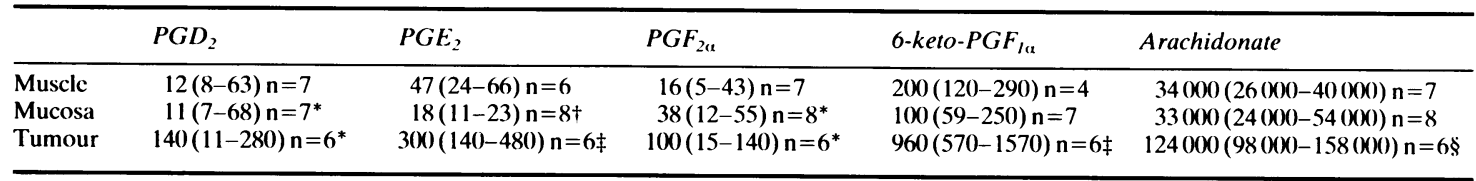

The results are ng/g shown as median with semiquartile ranges in parentheses. Comparison between 6-keto-PGF ${ }_{1,4}$ and other prostaglandins within each specimen (Wilcoxon's test): ${ }^{*} p<0 \cdot 05 ; \uparrow p=0.01$. Since this paired test requires at least six specimens, $p$ values have not been calculated for the muscle. With the Mann-Whitney U-test, however, the differences between 6-keto-PGF ${ }_{1 / 1}$ and the other prostaglandins are $\mathrm{p}<0 \cdot(01$. Tumour $v s$ mucosa for each prostaglandin: $\neq \mathrm{p}<0 \cdot 01$; arachidonate $\$ p<0 \cdot 002$ (Mann-Whitney U-test). There were no significant differences in prostanoid content of muscle compared with mucosa $(p>0 \cdot 1)$. Only seven specimens of muscle were available. Where the numbers of muscle and mucosa are less than seven and cight respectively, the samples were lost. 
Table 2 Quantitative measurement of prostaglandins and free arachidonate in extracts of large bowel tissues by GC-MS

\begin{tabular}{|c|c|c|c|c|c|}
\hline & $P G D_{2}$ & $P G E_{2}$ & $P G F_{2 u}$ & 6-keto-PGF Ile & Arachidonate \\
\hline Muscle $(n=12)$ & $13(11-135)^{*}$ & $17(8-36) \div$ & $30(8-89)^{*}$ & $230(120-370)$ & $42000(22000-440000)$ \\
\hline $\begin{array}{l}\text { Large bowel mucosa } \\
\qquad(\mathrm{n}=12)\end{array}$ & $14(12-35) \dagger$ & $22(19-31) \dagger$ & $14(10-22) \dagger$ & $270(130-360)$ & $31000(29000-32000)$ \\
\hline $\begin{array}{l}\text { Large bowel tumour } \\
\qquad(\mathrm{n}=8)\end{array}$ & $17(12-84) \dagger$ & $96(64-100)+\ddagger$ & $14(11-190)+$ & $400(395-460) \ddagger$ & $142000(124000-173000)$ \\
\hline
\end{tabular}

Results are ng/g. shown as medians with semiquartile ranges in parentheses. There were 13 patients, but one sample each of muscle and mucosa were lost. Comparisons between 6-keto-PGF 1 a and other prostaglandins within each specimen: ${ }^{*} p<0 \cdot 05$; ${ }^{+} p<0 \cdot 01$ (Wilcoxon's test). Tumour vs mucosa for each substance: $\ddagger \mathrm{p}<0 \cdot 05 ; \$<0 \cdot($ ())2 (Mann-Whitney U-test). There were no significant differences in prostanoid content of muscle compared with mucosa.

seven colon tumours yielded more 6-keto- $\mathrm{PGF}_{1 \alpha}$ than the corresponding normal mucosa.

\section{Discussion}

Our previous results showed that homogenisation in Krebs solution increases the formation of prostaglandins, presumably because arachidonate is released during tissue disruption. ${ }^{3}$ The quantitative measurements of $\mathrm{PGD}_{2}, \mathrm{PGE}_{2}, \mathrm{PGF}_{2 \alpha}$, 6-keto$\mathrm{PGF}_{1 \alpha}$ and arachidonate by GC-MS selective ion monitoring show that the extracted homogenates of macroscopically normal gastrointestinal tissues and tumours contained predominantly arachidonate, with 6-keto-PGF $\mathrm{P}_{1 \alpha}$ as the most abundant metabolite. We did not, however, determine the losses in the individual samples, and although this seems unlikely to be an important factor it might distort the relative amounts.

Using radioimmunoassay of human gastric mucosal incubates, Jeremy et al" also found that the prostanoid yield was 6-keto- $\mathrm{PGF}_{1 \alpha}>\mathrm{PGE}_{2}>\mathrm{PGF}_{2 \alpha}$, and Whittle and Salmon ${ }^{\times}$found a slightly greater production of 6-keto-PGF ${ }_{1 \alpha}$ than of $\mathrm{PGE}_{2}$. In contrast, Peskar et al, ${ }^{7}$ obtained more $\mathrm{PGE}_{2}$ than 6-keto$\mathrm{PGF}_{1 \alpha}$ with endogenous substrate, and Ahlquist $e t$ $a l,{ }^{12}$ found that the prostanoid formation from $\left[{ }^{14} \mathrm{C}\right]-$ arachidonic acid by human fundic mucosa was $\mathrm{PGE}_{2}$ $>\mathrm{PGD}_{2}=\mathrm{PGF}_{2 \alpha}>6$-keto- $\mathrm{PGF}_{1 \alpha}>\mathrm{TXB}_{2}$.

With regard to the colon, Boughton-Smith et $a l^{13}$ homogenised five specimens of human colonic mucosa and then incubated them with exogenous $\left[{ }^{14} \mathrm{C}\right]$-arachidonic acid. Their yields were $\mathrm{PGE}_{2}>\mathrm{PGF}_{2 \alpha}>\mathrm{PGD}_{2}>\mathrm{TXB}_{2}>6$-keto-PGF $\mathrm{PG}_{1 \alpha}$, in contrast with our finding of most 6-keto-PGF $F_{1 \alpha}$.

The reasons for different prostaglandin yields obtained by the various groups is likely to be partly methodological, but there are other factors such as losses during extraction and preparation for assay, and variables such as each patient's age, sex, disease, and medication.

Exact measurements of prostanoid formation may well be of value in studying aspects of physiology and pathology, provided that the samples are obtained, extracted and assayed under standardised conditions. There is little merit, however, in making comparisons when this is not the case, and we must also bear in mind that different cell types in the tissues, including blood elements, contribute to the yield. Nevertheless, it is important to know what types of prostanoids can be produced by tissues, and whether their amounts might be sufficient to affect the biological activity. Our results with gas chromatography - mass spectrometry, a method without the specificity problems of other assays, suggests that this may be so for various prostanoids.

With regard to gastrointestinal malignancy, previous work has shown that human colonic cancer cells released more PGE-like substance than did normal cells. ${ }^{14}$ Gastrointestinal tumours often, but not always, produced more PG-LM than normal mucosa, as judged by bioassay on rat gastric fundus, ${ }^{3}$ and many other cancers produce raised amounts of prostaglandins (see ref $^{15}$ ). In the present experiments, extracts of large bowel tumours usually contained more prostaglandins than did those of the associated normal mucosa, and gastric carcinomas always did so. The reason why tumours form more prostaglandins than the normal tissue in which they arise has received little study. Hong et $\mathrm{l}^{\text {lh }}$ found that transformed 3T3 fibroblasts had a raised amount of prostaglandin synthetase. Our results indicate that the reason may be the greater amount of arachidonate. We do not know yet if this results from increased activity of enzymes such as phospholipase $\mathrm{A}_{2}$ that release the arachidonate, or whether more precursor is present in the cancer cells.

We would like to thank the Medical Research Council, The Cancer Research Campaign, and The Association for International Cancer Research for support, the many surgeons who provided the tissues, and the Departments of Morbid Anatomy, King's College School of Medicine and Dentistry and Dulwich Hospital, London, for their help. 


\section{References}

1 Bennett A, Hensby CN, Sanger GJ, Stamford IF. Metabolites of arachidonic acid formed by human gastrointestinal tissues and their actions on the muscle layers. BrJ Pharmacol 1981; 74: 435-44.

2 Bennett A, Murray JG, Wyllie JH. Occurrence of prostaglandin $E_{2}$ in the human stomach, and a study of its effects on human isolated gastric muscle. BrJ Pharm Chemother 1968; 32: 339-49.

3 Bennett A, Stamford IF, Unger WG. Prostaglandin $E_{2}$ and gastric acid secretion in man. J Physiol 1973; 229: 349-60.

4 Bennett A, Stamford IF, Stockley HL. Estimation and characterisation of prostaglandins in the human gastrointestinal tract. BrJ Pharmacol 1977; 61: 579-86.

5 Bennett A, del Tacca M, Stamford IF, Zebro T. Prostaglandins extracted from tumours of human large bowel. Br J Cancer 1977; 35: 881-4.

6 Sinzinger H, Silberbauer K, Winter M, Seyfried M. Human rectal mucosa generates prostacyclin. Lancet 1978; ii: 1253.

7 Peskar BM, Seyberth HW, Peskar BA. Synthesis and metabolism of endogenous prostaglandins by human gastric mucosa. In: Samuelsson B, Paoletti R, eds. Advances in prostaglandin and thromboxane research. New York: Raven Press, 1980; 8: 1511-4.

8 Whittle BJR, Salmon JA. Endogenous secretagogues and diarrhoeal disease in intestinal secretion. In: Turnberg LA, ed. Intestinal Secretion. Proceedings of the Third BSG SK and F International Workshop.
Welwyn, Herts: Smith, Kline and French Laboratories Ltd, 1982: 69-73.

9 Jeremy JY, Mikhailidis DP, Dandona P. The effect of tiaprofenic acid and indomethacin on in vitro prostaglandin synthesis by rat, rabbit and human stomach tissue. Agents Actions 1985; 17: 205-8.

10 Unger WG, Stamford IF, Bennett A. Extraction of prostaglandins from human blood. Nature 1971; 233: 336-7.

11 Andersen NH. Preparative thin layer and column chromatography of prostaglandins. J Lipid Res 1969; 10: 316-9.

12 Ahlquist DA, Duenes JA, Madson TH, Romero JC, Dozois RR, Malagelada JR. Prostaglandin generation from gastroduodenal mucosa; regional and species differences. Prostaglandins 1982; 24: 115-25.

13 Boughton-Smith NK, Hawkey CJ, Whittle BJR. Biosynthesis of lipoxygenase and cyclo-oxygenase products from $\left[{ }^{14} \mathrm{C}\right]$-arachidonic acid by human colonic mucosa. Gut 1983; 24: 1176-82.

14 Jaffe BM. Prostaglandins and cancer: an update. Prostaglandins 1974; 6: 453-61.

15 Bennett A. Prostaglandins and inhibitors of their synthesis in cancer growth and spread. In: Rose DP, ed. Endocrinology of cancer. Vol. 3. Florida: CRC Press Inc. 1982: 113-27

16 Hong SL, Polsky-Cynkin R, Levine L. Stimulation of prostaglandin biosynthesis by vasoactive substances in methylcholanthrene-transformed mouse BALB/3T3. J Biol Chem 1976; 251: 776-80. 